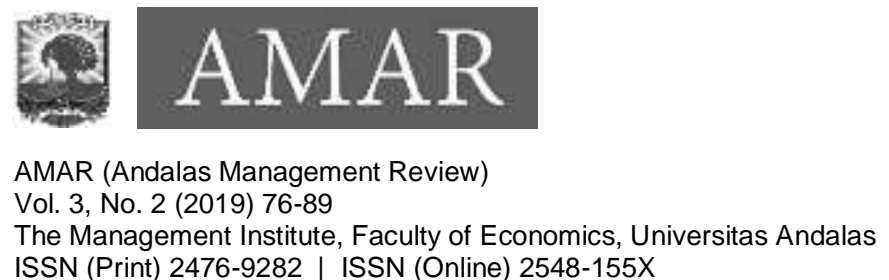

\title{
Determinants of Dividend Policy of Listed Commercial Banks in Indonesia
}

\author{
Gina Auliaa, Mohamad Fany Alfarisi ${ }^{b}$ \\ "Ministry of Social Affairs Republic of Indonesia \\ ${ }^{b}$ Departmen of Management, Faculty of Economics Universitas Andalas
}

\begin{abstract}
This study aims to identify the determinants of dividend payout policy of publicly listed banks in Indonesia. The data were collected from annual reports and databases related to the research sample. The present study employs the dynamic panel data model using the Generalized Methode of Moment (GMM) approach. The results without control variables suggest that lagged dividend payout, profitability, and firm size positively impact dividend payout. Meanwhile, using control variables, the present study finds only liquidity that significantly impacts the dividend payout.
\end{abstract}

Keywords: Dividend Payment Policy, Generalized Method of Moment, Bank

\section{INTRODUCTION}

Dividend policy has been one of the most debatable topics in the finance literature. The discourse on dividend policy so far has attracted the attention of academics to solve the dividend puzzle. The questions surrounding dividend policy (puzzle) lie in how people perceive their impact on a firm's value.

In corporate finance, financial managers need to make decisions on four essential and interrelated matters: financing, investment, dividend policy, and working capital decisions. Financing decision is related to the source of funds for the firm operation and investment. The investment decision is concerned with what fixed assets the firm should acquire, and dividend policy is related to how the firm distributes earnings as dividends and retained earning.

There are two returns shareholders can earn from their investment, namely dividends and capital gains. Meanwhile, from a corporate perspective, dividend payout is the cash outflow that 
will reduce the company's cash. Therefore, the dividend distribution decisions are a necessary consideration for the company's growth and its sustainability.

A bank is an intermediary institution that channels funds from public funds and trust both within and outside the country. Commercial banks conduct several activities, notably collecting deposits and advancing loans and other fee-based activities. The number of provisions governing the banking sector to protect the community's interests, including the provisions governing the obligation to meet the minimum capital per each bank's conditions, make the banking sector a highly regulated. The banking sector is a critical part of the economy and performs an essential role in the economic activities; in the current era, the economy cannot act without an adequate banking system (Ahmed et al., 2018).

Bank Indonesia (BI) -as a central bank in Indonesia- plans to make macroprudential policy to ease banking dividends in line with its performance in the current year to maintain banking liquidity. Amid global uncertainty, BI considers the space for monetary easing to be narrower, so the need for policy breakthroughs to ensure adequate banking liquidity. Therefore, the regulation of dividend payments needs to be assessed in order to keep the banking finance.

The paper is structured as follows: Section 2 reviews the relevant literature on the dividend payout policy and the research hypothesis. Section 3 describes the research method. Section 4 provides details on the results of the study. And the conclusion on section 6.

\subsection{Literature Review}

The dividend policy is an inseparable part of the company's funding decisions. The decision about profit distribution is essential, whether the profit will be distributed in dividends or retained and reinvested. The dividend policy is a crucial decision for the company because dividends are sources of income for investors and reflect its performance.

Dividend policy is vital because the intrinsic model holds that a stock's price is the present value of its future dividends (Dickens et al., 2002). Lintner (1956) argues that most managers are unwilling to reduce their companies' dividend payments because they feel such a decision would hurt their companies' stock prices. The managements him interviewed very generally believed that, unless there were other compelling reasons to the contrary, their fiduciary responsibilities and standards of fairness required them to distribute part of any substantial increase in earnings to the stockholders in dividends. 
Lagged dividend refers to cash dividends paid to investors one year before the year under consideration. Because firms favor a stable dividend policy, past dividend trends are significant enough to affect current dividend payments (Al-Kayed, 2017). Companies are usually reluctant to lower the amount of dividends from last year because it will negatively signal shareholders. MM argued that a higher than expected dividend increase signal investors that the firm's management forecasts good future earnings (Brigham \& Ehrhardt, 2015). So the company can make the amount of dividend payout last year as consideration to determine the current dividend.

Because firms prefer a stable dividend policy, past dividend trends are significant to affect current dividend payments and, as such, variables have been included as essential determinants of dividend policy. Based on the findings of Dickens et al. (2002), Imran (2011), Al-khadhiri \& Alzomaia (2013), Zameer et al. (2013), Abdella (2016), lagged dividend has a significant positive effect on dividend payout.

The profitability of a company is measured by the company's success and the ability to use its assets productively; thus, the profitability of a company can be known by comparing the profit earned in a period with the amount of assets or capital in the company. High profitability can provide a positive signal, both for internal and external companies. Companies that have high profitability will attract investors to invest in the hope of getting high profits too. Baker et al. (2001) investigate the views of managers of large corporations in the United States about the factors that influence dividend policy. They found that past, present, and future earnings have a unique dividend pattern. Profitable companies pay more significant dividends compared to less profitable companies. Many studies have been conducted and concluded that profitability is a major factor affecting dividends. The result of Imran (2011), Eng et al (2013), Zameer et al (2013), Zhang (2014), Atairet (2014), Odawo \& Ntoiti (2015), Al-khadhiri \& Alzomaia (2013), Augusto \& Forti (2015), Ahmad \& Fahid (2016) and Kathuo \& Kimoro (2017) show that profitability have positive significant effect to dividend policy. (Badu, 2013) (Devanadhen \& Karthik, 2015) show that profitability has a negative effect on dividend policy.

The cash flow statement is a statement of sources and uses of cash that tend to quantify all of a company's cash inflows and outflows in a manner that the typical income statement and the balance sheet do not. Without cash flow data, a company and its executives could potentially end up in a worst possible position and ultimately collapse. In terms of liquidity analyses and 
examination, cash flow information is more reliable than the income statement and balance sheet information (Amuzu, 2010). Dividends are cash outflows; the company with a good cash position and liquidity can pay dividends. If management wants to maintain liquidity to protect uncertainty and financial flexibility, it won't pay dividends with a large portion. La Porta et al. (2000) in Badu (2013) argued that when a firm has a free cash flow, its managers will engage in wasteful practices, even when inventors' protection improves. Some studies have suggested that firms with a more significant "cash flow" need to pay more dividends to reduce the free cash flow's agency costs. According to agency theory, firms may overcome misuse of free cash flow by management through dividend distribution (Yusof \& Ismail 2016, Al-Kayed 2017). Liquidity is considered the primary determinant of dividend policy compared to net income. The results of Imran (2011), Zameer et al. (2013), Odawo \& Ntoiti (2015), and Devanadhen \& Karthik (2015) stated that liquidity had a significant adverse effect on dividend payout. The result of Augusto \& Forti (2015), Badu (2013) liquidity variable was positive and significant.

Growth and investment as determinants of dividend policy align with the agency cost theory, whereby firms with no growth or fewer investment opportunities have greater exposure to agency costs related to free cash flows. In reducing the agency costs, these firms will pay higher dividends to the shareholders than firms with high growth and greater investment opportunities (Jensen, 1986 in Yusof \& Ismail, 2016). Companies with growth opportunities divide fewer dividends to maintain a larger portion of their income to finance growth (Rozeff, 1982). It means that a company with high revenue growth reduces the proportion of dividend payouts and chooses to hold it in retained earnings to finance future growth or investment. The company does not require a large external funding source. In view of this means that dividend payments are negatively correlated with income growth rates. The study was supported by findings of who found do not have any significant impact growth opportunities on the dividend Dickens et al. (2002), Zameer et al. (2013) (Devanadhen \& Karthik, 2015). In contrast to the study, Eng et al. (2013) Imran (2011), Augusto \& Forti (2015), Abdella (2016) Jahanzeb et al. (2016) found growth opportunities have a significant impact on the dividend.

In Mehta (2012), large companies generally have a greater chance of paying dividends than smaller companies. This is because large companies have better access to the capital market. Therefore, it put the big size company in an advantageous position in capital accumulation. Hence, it allows them to distribute more generous dividends to the shareholders. So it can be 
deduced that larger firms have more stable cash flow operations so that their chances of distributing dividends are more significant than smaller firms. Based on the agency cost theory, larger firms' widespread ownership decreases the shareholders' ability to monitor the firm's internal and external financing activities, leading to more significant information asymmetry, thereby increasing agency costs. The dividend payment is an approach to mitigate the problem. In other words, larger firms tend to pay higher dividends than smaller firms (Yusof \& Ismail, 2016). In a study conducted by Dickens et al. (2002), Imran (2011), Augusto \& Forti (2015), Yusof \& Ismail (2016) showed that there was a significant positive correlation between firm size and dividend payout. Zameer et al., (2013), Devanadhen \& Karthik (2015), Odawo \& Ntoiti (2015), Jahanzeb et al. (2016) showed that there was an insignificant correlation between firm size and dividend payout. Based on the results of the above research, the researchers hypothesized that: H1: lagged dividend has a positive effect with dividend payout H2: Profitability has a positive effect with dividend payout H3: Liquidity has a negative effect with dividend payout H4: Revenue growth has a positive effect with dividend payout

\section{METHOD}

\subsection{Data and Sample}

The data would be gathered from annual reports and databases related to the research sample. This study's population are commercial banks listed on the Indonesia Stock Exchange (BEI) period 2011-2016. Determination of sampling using a purposive sampling method, that is the selection of sampling only banks that meet specific criteria. The criteria include the following banking companies listed on Indonesia Stock Exchange (IDX), publish annual report, have complete data related to the variables used in this study and the company distributes cash dividends at least once during the study period, which is the year 2011-2016. So that from 43 banks that have listing, only 15 banks meets the criteria to using for research sample.

\subsection{Data analysis}

This study examines the determinants of dividend payout policy with dividend payout as the dependent variable, independent variables is lagged dividend payout, profitability, liquidity, revenue growth and firm size as control variables. 
. This research uses Generalized Method of Moment (GMM) related to Arellano \& Bond (1991) and Blundell \& Bond (1998) method to uncover the determinants of dividend payment policy at a listed bank in Indonesia Stock Exchange by doing sargan test, Arellano-Bond test and Wald test. In Mileva (2007) there are some problems in the econometrics that arise so the GMM estimator picks:

a. Independent variable assumed to be endogenous. Because causality may run in both directions, these regressors may be correlated with the error term.

b. Time-invariant country characteristics (fixed effects), such as geography and demographics, may be correlated with the explanatory variables. The fixed effects are contained in the error term in equation, which consists of the unobserved country-specific effects, $v$, and the observation-specific errors, $e_{i t}$ :

$$
\text { c. } u i t=v i+e i t
$$

d. The presence of the lagged dependent variable $(i, t-1)$ gives rise to autocorrelation.

e. The panel dataset has a short time dimension $(T=6)$ and a larger country dimension $(N$ $=15)$.

To solve problem 1 (and problem 2) one would usually use fixed-effects instrumental variables estimation (two-stage least squares or 2SLS). Mileva (2007) reveals that in her previous research, first-stage statistics of 2SLS regression showed that the instruments used were weak. With weak instruments, the fix-effect IV estimator tends to be biased in line with the OLS estimator. Then she conducted a study using the and Blundell \& Bond (1998) GMM estimator. Using the GMM estimator makes the endogenous Arellano \& Bond (1991) variable not correlated with the term error. Another purpose of GMM use is to address downward (upward) biased on OLS and fixed effects (Badinger et al,. 2002). In addition, according to Wooldridge (2002) in Hasriati (2016) use of GMM methods is also necessary because there are lag dependent variables in the model that may cause endogenous problems. To overcome the problem of fixed-effects estimator GMM use change equation so that equation in this research become:

$$
\Delta \mathrm{DY}_{i t}=\Delta \mathrm{DY}_{i, t-1}+\Delta \mathrm{ROA}_{i t}+\Delta \mathrm{CASH}_{i t}+\Delta \mathrm{MTB}_{\mathrm{it}}+\Delta \mathrm{SIZE}_{i t}+\Delta \mu_{i t}
$$

DY $_{i t} \quad=$ Dividend yield in year $_{t}$

$\mathrm{DY}_{i, t-1} \quad=$ Dividend yield in year $_{t-1}$ 


$\begin{array}{ll}\mathrm{ROA}_{i t} & =\text { Return on asset in year } \\ \mathrm{CASH}_{i t} & =\text { Cash flow in year } \\ \mathrm{MTB}_{i t} & =\text { Market-to-book in year } \\ \mathrm{SIZE}_{i t} & =\text { Firm size in year } \\ u_{i t} & =\text { error } \\ i & =\{1, \ldots, \mathrm{N}\} \\ t & =\{1, \ldots, \mathrm{T}\}\end{array}$

Table 1

Proxy Variable

\begin{tabular}{lcc}
\hline \multicolumn{1}{c}{ Variable } & \multicolumn{1}{c}{ Symbol } & Proxy \\
\hline Dividend & DY & DY $=\frac{\text { Dividend per Share }_{\mathrm{t}}}{\text { Market Value per Share }_{\mathrm{t}}}$ \\
\hline Lagged Dividend & Lagged DY & Lag DY $=\frac{\text { Dividend per Share }_{\mathrm{t}-1}}{\text { Market Value per Share }_{\mathrm{t}-1}}$ \\
\hline Profitability & ROA & ROA $=\frac{\text { Net Income }}{\text { Total Assets }}$ \\
\hline Liquidity & CASH & Cash Flow $=\frac{\text { Cash and Cash Equivalent }}{\text { Net Total Assets }}$ \\
\hline Revenue Growth & MTB & MTB $=\frac{\text { Market Value per Share }}{\text { Book Value per Share }}$ \\
\hline Firm Size & SIZE & Firm Size $=$ ln (total asset) \\
\hline
\end{tabular}

Source: Output Stata (2018)

\section{RESULTS AND DISCUSSION}

\subsection{Sargan Test}

Sargan Test conducted in this study to test the validity of the instrument. Test the null hypothesis that the instrument variable used is valid. The expected test result is the accepted null hypothesis, the expected value with $a>0.05$ which means not enough evidence to deny that the instrument variable used is valid (instrument variable not correlated with error).

Table 2

\section{Result of Sargan Validity Test}


Andalas Management Review, Vol. 3, No. 2, 2019

\begin{tabular}{lc}
\hline chi2 (13) & $\mathbf{1 0 . 6 3 4 7}$ \\
\hline Prob > chi2 & 0.6414 \\
Source: Output Stata (2018)
\end{tabular}

Dynamic model instrument validity test used in this study by conducting Sargan test seen from the probability value of 0.6414 which is not significant at the real level $\alpha=0.05$ and $\alpha=0.01$. This shows that there is no correlation between residue and over-identification restrictions, so there is no problem with instrument validity.

a. Arellano-Bond Test

The Arellano-Bond test was conducted to determine that the dynamic panel model with using GMM estimated to met the consistent criteria. To see the consistency of estimation result from AB-GMM model will be test autocorrelation by using Arellano-Bond $m_{1}$ and $m_{2}$ statistic. This consistency is indicated by significant result from $m_{1}(\alpha<0,05)$ statistically and unsignificant result $m_{2}(a>0.05)$ statistically (Arellano, 2003).

\section{Table 3}

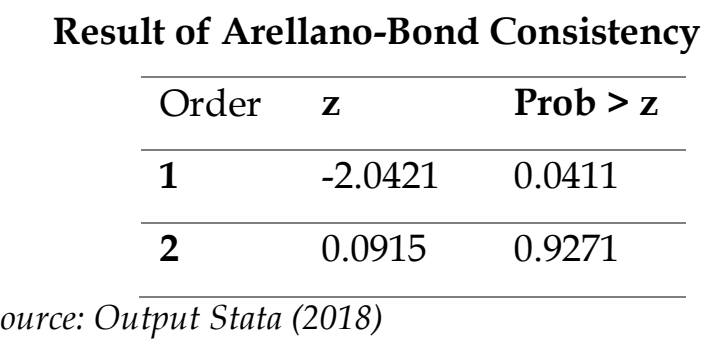

In the Arellano-Bond test, we can see the value of (Prob> z) statistical value m1 (-2.0421) with a significant probability of 0.0411 at the significant level $\alpha=0.05$ and $\alpha=0.10$ and the statistical value $\mathrm{m} 2(0.0915)$ with the probability 0.9271 which is not significant at the real level of $a=0.01, a=0.05$ and $\alpha=0.10$, so it can be said consistent estimator.

b. Wald Test

This wald test is used to test the significance of the model's parameters simultaneously between the dependent variable and the independent variable. Use of the best model is System-GMM (SYS-GMM) noconstant and two step efficient estimator. The method as according to Blundel-Bond (1998) which from the results of his research found that the estimated parameters by Arellano-Bond (1991) is still less efficient. This is because the moment of the condition and the variable matrix used by Arellano-Bond only includes its first difference model only. And two efficient step is used because the results obtained more efficient. The use of SYS-GMM model is supported by Hasriati (2016) results that 
based on the estimation result, it is proven that the SYS-GMM method is more efficient and consistent than AB-GMM method.

Table 4

\section{Result of Wald Significance Test without Control Variable}

\begin{tabular}{llll}
\hline DY & $\begin{array}{l}\text { Estimated } \\
\text { Coefficients }\end{array}$ & $\begin{array}{l}\text { Standard } \\
\text { Error }\end{array}$ & $\mathrm{P}>|\mathrm{z}|$ \\
\hline Lagged DY & 0.4544 & 0.0265 & 0.000 \\
\hline ROA & 0.4892 & 0.0485 & 0.000 \\
\hline CASH & -0.0160 & 0.0031 & 0.000 \\
\hline MTB & 0.0000 & 0.0000 & 0.219
\end{tabular}

Source: Output Stata (2018)

Table 5

Wald Significance Test with Control Variable

$\begin{array}{llll}\text { DY } & \text { Estimated } & \text { Standard } & \mathrm{P}>|\mathrm{z}| \\ & \text { Coefficients } & \text { Error } & \end{array}$

\begin{tabular}{lccc}
\hline Lagged DY & 0.3942 & 0.0534 & 0.000 \\
\hline ROA & 0.3133 & 0.0628 & 0.000 \\
\hline CASH & -0.0785 & 0.0096 & 0.000 \\
\hline MTB & 0.0000 & 0.0001 & 0.859 \\
\hline SIZE & 0.0009 & 0.0002 & 0.000
\end{tabular}

Source: Output Stata (2018)

The result show that by using or not using control variable, there is no significant

difference from result of estimation. Lagged DY, ROA, and SIZE variables have a significant positive effect on dividend payout, $\mathrm{CASH}$ has significant negative effect on dividend payout and MTB has no significant positive effect on dividend payout. So H1 (Lagged Dividend), H2 (Profitability) and H3 (Liquidity) are accepted and H4 (Revenue Growth) is rejected.

The positive relationship between dividend of this period is influenced by the dividend of the previous period. This means, in determining the amount of dividends paid in this 
year, shareholders and management of the company compare or guided by dividend payout in the previous year. Management tends to maintain a dividend or increase the amount of dividend payouts for the next period because dividend reductions will send a negative signal to the market. This result is consistent with Miller \& Rock, (1985) stating that the dividend payout ratio gives investors signals about future company performance. Conversely, dividend reductions are perceived as bad news because it sends a negative signal to investors about future earnings of the company. The results of this study support the research of of Dickens et.al (2002), Imran (2011), Al-khadhiri \& Alzomaia (2013), Zameer et.al (2013), and Abdella (2016).

Profitability variable has a positive and significant effect on dividend payout, which means that the profit to be shared by the company is very influential on the condition of return on asset company. The results of this study are supported by Imran (2011), Eng et al (2013), Zameer et al (2013), Zhang (2014), Atairet (2014), Odawo \& Ntoiti (2015), Al-khadhiri \& Alzomaia (2013), Augusto \& Forti (2015), Ahmad \& Fahid (2016) and Kathuo \& Kimoro (2017).

Liquidity variables have a negative and significant effect on dividend payout policy. This negative relationship means that if an increase in dividend payout will affect the company's liquidity. This is because the main business of banking is related to cash that can be immediately cashed which transactions in the banking today can be made at any time, so the bank must have the amount of cash available in order to meet customer transactions. At the moment the bank makes a dividend payment at once, it is likely that there will be a shake-up of banking liquidity, so there is a negative relationship between liquidity and dividend payout. The results of this study are supported by the results of Imran (2011), Zameer et.al (2013), Odawo \& Ntoiti (2015) and Devanadhen \& Karthik (2015).

The results of this study there is no significant positive relationship between revenue growth and dividend payout. This means, despite an increase in revenue growth, it does not mean there will be an increase in dividend payout. This is in line with research conducted by Rozeff (1982) companies with growth opportunities to distribute fewer dividends to maintain a larger portion of their income to finance growth. This means that a company with high revenue growth reduces the proportion of dividend payouts and 
chooses to hold it in retained earnings to finance future growth or investment so that the company does not require a large external funding source. This study is in accordance with Dickens et al. (2002), Zameer et.al (2013), Devanadhen and Karthik (2015), Abdella (2016) which states that revenue growth has no effect on dividend payout.

Based on the results of this study shows that the firm size have a positive and significant effect on dividend payout policy. The positive coefficient value indicates that the larger the firm size, can distribute greater dividend to shareholders. The big and reputable company easily entered the capital market to provide benefits for the company in obtaining funds from investors, so the company has opportunity to pay dividends to shareholders in order to maintain the reputation of the company. In this study obtained the result that firm size and dividend payouts have a positive relationship. The results of this study are in line with research conducted by Dickens et.al (2002), Imran (2011), Augusto \& Forti (2015), Yusof \& Ismail (2016).

\section{CONCLUSION}

This study aims to examine the determinants of dividend payout policy inlisted banks in Indonesian in 2011-2016 with the dividend payout dividend as dependent variable, independent variable is lagged dividend payout, profitability, liquidity, revenue growth, and firm size as control variables.

The result found that by using or not using control variable there is no significant difference from the estimation result which can be seen from wald significant test, the result obtained that dividend lagged, profitability and firm size have positive significant effect to dividend policy, liquidity a significant negative effect on dividend policy and revenue growth have no significant positive effect on dividend policy.

\section{REFERENCES}

Abdella, A. B. (2016). A Study on the Determinants of Dividend Policies of Commercial Banks in Saudi Arabia, (9).

Ahmad, I., \& Fahid, M. (2016). AN EMPIRICAL STUDY OF BANKING SECTOR OF PAKISTAN. https://doi.org/10.19041/APSTRACT/2016/4-5/13

Ahmed, F., Rafay, A., \& Ahmed, A. (2018). Dividend Payout Policy of Conventional Banking and 
Islamic Banking in Pakistan, 10(January), 135-152.

Al-Kayed, L. T. (2017). Dividend payout policy of Islamic vs conventional banks: case of Saudi Arabia. International Journal of Islamic and Middle Eastern Finance and Management, 10(1), 117128. https:// doi.org/10.1108/IMEFM-09-2015-0102

Al-khadhiri, A., \& Alzomaia, T. S. (2013). Determination of Dividend Policy : The Evidence from Saudi Arabia, 4(1), 181-192.

Al-Malkawi, H. N., Rafferty, M., \& Pillai, R. (2010). Dividend Policy: A Review of Theories and Empirical Evidence. International Bulletin of Business Administration, 9(9), 171-200.

Amuzu, M. S. (2010). Cash Flow Ratio As a Measure of Performance of Listed Companies In Emerging Economies. Turks and Caicos Islands, 1-309.

Arellano, M., 2003, Panel Data Econometrics, Oxford University Press Inc., New York.

Arellano, M., \& Bond, S. R. (1991). Some tests of specification for panel data: Monte Carlo evidence and an application to employment equations. ,58, 277-297. Review of Economic Studies, (58), 277-297.

Atairet, E. A. (2014). DETERMINANTS OF DIVIDEND PAYOUT OF FINANCIAL INSTITUTIONS IN NIGERIA : A STUDY OF SELECTED, 5(7), 74-79.

Augusto, C., \& Forti, B. (2015). Determinant Factors of Dividend Payments in Brazil *, 1-14. https://doi.org/10.1590/1808-057×201512260

Badinger, H., Müller, W. G., \& Tondl, G. (2002). Regional convergence in the European Union 1985-1999: A spatial dynamic panel analysis. Regional Studies, (HWWA Discussion Paper Regional 210), 1-25. https:/ / doi.org/10.1080/003434042000211105

Badu, E. A. (2013). Determinants of Dividend Payout Policy of listed Financial Institutions in Ghana, 4(7), 185-191.

Blundell, R. W., \& Bond, S. R. (1998). Initial Conditions and Moment Restrictions in Dynamic Panel Data Models. Journal of Econometrics, 87, 115-143.

Brigham, E. F., \& Ehrhardt, M. C. (2015). Financial Management: Theory and Practice (13th ed.). Canada: South-Western, a part of Cengage Learning.

Devanadhen, K., \& Karthik, P. (2015). DETERMINANTS OF DIVIDEND POLICY OF PUBLIC AND PRIVATE COMMERCIAL BANKS IN INDIA : Journal of Arts, Science E Commerce, 6(3), 111-121.

Dickens, R. N., Casey, K. M., \& Newman, J. a. (2002). Bank Dividend Policy: Explanatory Factors. 
Quarterly Journal of Business and Economics, 41(1), 3-12. https:// doi.org/10.2307/40473341

Eng, S., Yahya, M., \& Hadi, A. (2013). The Dividend Payout Policy - A Comparison On Malaysian Islamic And Conventional Financial Institutions. Journal of WEI Business and Economics, 2(2), $12-20$.

Imran. (2011). Determinants of Dividend Payout Policy : A Case of Pakistan Engineering Sector. The Romanian Economic Journal, (41), 47-60.

Jahanzeb, A., Memon, P. A., Tunio, J. A., \& Shah, S. S. A. (2016). IMPACT OF CORPORATE GOVERNANCE AND FIRM-LEVEL CONTROL VARIABLES ON DIVIDEND POLICY OF SERVICE TRADE SECTOR OF MALAYSIA. Journal of Economic and Social Development, 3(2), 102-111.

Kathuo, S. M., \& Kimoro, J. N. (2017). Determinants of Dividend Policy Decisions of the Listed Banks in Kenya, 7, 16-21.

Lintner, J. (1956). Distribution of Incomes of Corporations Among Dividens, Retained Earnings , and Taxes John Lintner The American Economic Review, Vol . 46, No . 2, Papers and Proceedings of the Sixty-eighth Annual Meeting of the American Economic Association . ( May ,. Taxes, 46(2), 97-113.

Mehta, A. (2012). An Empirical Analysis of Determinants of Dividend Policy - Evidence from the UAE Companies. Global Review of Accounting and Finance, 3(1), 18-31.

Mileva, E. (2007). Using Arellano - Bond Dynamic Panel GMM Estimators in Stata, 0(1), 1-10.

Miller, M. H., \& Rock, K. (1985). Dividend Policy under Asymmetric Information. The Journal of Finance, 40(4), 1031-1051. https:/ / doi.org/10.1111/j.1540-6261.1985.tb02362.x

Odawo, C., \& Ntoiti, J. (2015). Determinants of Dividend Payout Policy in Public Ltd Banks in Kenya: A Case Study of CFC Stanbic Bank. The Strategic Journal of Management, 2(54), 182191.

Rozeff, M. S. (1982). Growth, beta and agency costs as determinants of dividend payout ratios. The Journal of Financial Research, V(3), 249-259.

Yusof, Y., \& Ismail, S. (2016). Determinants of dividend policy of public listed companies in Malaysia. Review of International Business and Strategy, 26(1), 88-99. https://doi.org/10.1108/RIBS-02-2014-0030

Zameer, H., Rasool, S., Iqbal, S., \& Arshad, U. (2013). Determinants of Dividend Policy : A Case of Banking Sector in Pakistan, 18(3), 410-424. 
Andalas Management Review, Vol. 3, No. 2, 2019

https:// doi.org/10.5829/idosi.mejsr.2013.18.3.12200

Zhang, X. (2014). Does Ownership Structure Matter for Dividend Yield ? Evidence from the Hong Kong Stock Exchange, 4(2). https:/ / doi.org/10.5296/ber.v4i2.6023 